\title{
Jakub Razim, Věrní Přemyslovci a barbarští Čechové: Česko-ř́íšské vztahy $v$ raném a vrcholném středověku, Leges, Praha 2017, ss. 416
}

$\mathrm{Na}$ otázku, ako d'alej s právnou medievistikou odpovedá nová kniha brnianskeho autora Jakuba Razima Věrní Přemyslovci a barbarští Čechové. Téma tejto knihy patrí ku klúčovým v českých dejinách. Zdôrazňovat význam vztahu Čiech a stredovekej rímskej ríše by bolo akiste zbytočnostou, stačí azda poukázat' na to, že sa z česko-nemeckých vztahov a zložitého, no obohacujúceho spolužitia zrodilo aj uvažovanie o zmyslu českých dejín. Nebudeme však radšej špekulovat nad tým, či dejiny môžu nejaký zmysel mat'. Uvedené slová uvádzame, aby sme zdôraznili obtiažnost' úlohy, spočívajúcej v spracovaní témy, pri ktorej je bádatel' ovplyvňovaný tradíciami bádania, modelmi, koncepciami a vedeckými spormi. Tie sú často vedené nielen o podstatu týchto vztahov, ale aj o tie najmenšie podrobnosti. Rôzne interpretované a formulované detaily sa nám napokon vlievajú do celku, ktorý sa nám snaží vniest' poriadok do chaotickej spleti informácií.

Sile týchto tradičných modelov nie je jednoduché sa vyhnút. Už len preto, že téma vztahu Čiech a ríše mala z objektívnych príčin svoje úskalia dané nacionálnymi spormi Čechov a Nemcov, a že aj tie najlepšie práce k nej bývali v tieni aktuálnych vztahov. Schematickost' a strnulost' tejto témy je navyše omnoho citel'nejšia, pokial' sa k nej pristupuje zo zdanlivo čistých právno-historických pozícií, nerešpektujúcich nezriedka špecifiká stredovekej pramennej bázy, pri ktorej sa musíme najmä $\mathrm{v}$ přemyslovskom období opierat' o naratívne texty. Tak tomu aspoň bolo dobrým zvykom v minulosti. Zdôrazňovanie štátneho charakteru včasnostredovekých útvarov, „analýza“ ich „orgánov“ a „inštitúcií," rozbor „medzinárodných vztahov“ zaplavovali texty mnohých štúdií a monografí, $\mathrm{v}$ ktorých sa autori pokúšali navliect' do 
modernej terminológie štátovedy včasnostredovekú latinskú terminológiu. Jakub Razim tak aj vzhladom $\mathrm{k}$ bohatej histórii bádania nestál pred jednoduchou úlohou. Preukázal však viac ako presvedčivo, prečo je aj v spoločenských vedách užitočná interdisciplinarita, vedecká spolupráca a kombinácia prístupov.

Ako bolo vyššie uvedené, téma nie je v prostredí českých spoločenských (historických) vied novinkou. A aj napriek tomu, že spadá do právnej medievistiky, tému možno pokladat' za aktuálnu najmä pre jej integračný aspekt, ktorý v európskom priestore bude prítomný azda vždy. Paralela o stredoeurópskych hlavách štátov, hl'adajúcich kompromisy medzi záujmami svojich krajín (a seba samých) so záujmami medzinárodného spoločenstva, bude očividne prítomnou konštantou a patrí k logike usporiadania cezhraničných vztahov.

Hladat však aktuálnost' len v týchto nejasných analógiách by bolo nenáležité, ak pripomenieme, že staršie dejiny sú vždy aktuálne i neaktuálne zároveň a tento stav je závislý najmä na konkrétnom čitatelovi a jeho vlastných potrebách. Tak medzi právnymi historikmi, ako aj medzi historikmi, sú medievistika a záujem o staršie dejiny azda z prirodzených dôvodov podrobené konfrontácii s aktuálnymi potrebami skúmania novších a moderných dejín. Niet sa vel'mi čomu čudovat'. Pramenná báza hovorí jasne v neprospech medievistiky, zvlášt' v súvislosti s obdobím, ktorému sa Jakub Razim venuje. To však na strane druhej neznamená, že je možné pokladat' stredovek za „preskúmaný“ a „prebádaný“. Táto monografia to dokazuje dostatočne, reprezentuje totiž vel'mi slubný pokus o nové ćítanie prameňov najmä ríšskej proveniencie s citom pre kritiku prameňov i dôslednú analýzu právnej terminológie, na ktorej základe autor predostiera spôsob právnického uvažovania prelomu včasného a vrcholného stredoveku. Následne prichádza výsledok v podobe možnosti revidovania historického odkazu, či historických predsudkov.

Práve tento osobitý prístup potvrdzuje, že ide o prácu v mnohom priekopnícku a originálnu. Jakub Razim sa neuspokojil s tradičným naratívnym prístupom bežným v historiografii, či schematickým zglajchšaltovaním včasno - a vrcholnostredovekých pomerov do terminológie modernej právnej vedy, kultivovanej najmä prácami 19. a 20. storočia.

Ked'že hlavnými prameňmi autora, z ktorých je možné právny pomer Čiech a ríše skúmat', sú ríšske kroniky a letopisy 10. a 11. storočia; monografia je štruktúrovaná práve na ich základe. Absencia statického právno-normatívneho ukotvenia vztahov Čiech a ríše vedie $k$ tomu, že objekt skúmania je potrebné analyzovat prostredníctvom dôslednej kritiky týchto prameňov. Pri nich Jakub Razim kombinuje metódy typické pre právnikov (analýza a výklad/interpretácia právnych pojmov) s metó- 
dami historickými (kritika prameňa). Prelínanie týchto metód je potom dané pramennou bázou, pri ktorej sú pramene práva súčasne literárnymi dielami, s ktorými je potrebné narábat v rovine sémantickej, sledovat motívy a ciele autorov jednotlivých diel, či pochopit dôvody rozkolísanosti termínov a pokúsit sa o ich čo najuspokojivejší preklad.

Pokial' ide o štruktúru práce, Jakub Razim hlavné kapitoly rozdelil na úvodnú kapitolu, v ktorej predostiera metodologické východiská a bohatý prehlad bádania. Následné kapitoly sú potom analýzou jednotlivých diel, a to kroniky Widukinda z Corvey (kap. 2) a Thietmara z Merseburgu (kap. 3), Altaišského letopisu (kap. 4), kroniky Lamperta z Hersfeldu (kap. 5) a Hildesheimského letopisu (kap. 6). Jednotlivé kapitoly sa následne členia na logicky štruktúrované podkapitoly. Patrí k nim charakteristika prameňa z pohl'adu rukopisného zachovania, cielov autora, jeho základné životopisné údaje (pokial' sú, pravda, známe), či prípadný vztah k Čechám. Ďalšia podkapitola býva charakterizovaná ako „ideový koncept Čech a říše“. Zjednodušene povedané, Razim tu charakterizuje, ako si autor prameňa predstavoval vztah Čiech a Přemyslovcov k ríši a k jej vládnucej dynastii. Tretia podkapitola je potom analýzou vyobrazení tejto idey na konkrétnych inštitútoch. Razim si všíma všetky spôsoby politickej komunikácie medzi přemyslovskými Čechami a ríšou, a to od tých konfliktných (vojna), cez uzmierovacie rituály (deditio), až po udržiavacie inštitúty (tribút, dary, vernost').

Razimove závery treba brat' ako logické a prijatel'né, metodické postupy ako prinajmenšom v našom priestore - originálne. Cennou je predovšetkým autorova strohost' v interpretáciách. Takáto strohost' však nie je dielom l'ahostajnejšieho vzt'ahu k dejinám, ako skôr pokusom o autentickejšie prerozprávanie stanovísk jednotlivých autorov. Často sa totiž stretávame s takou kritikou včasno - a vrcholnostredovekých prameňov, ktorá je založená na predsudkoch voči týmto prameňom. Verili sme preto, že ak je historická Pravda skrytá medzi riadkami, potrebujeme ju odtial',vydolovat'. Tento prístup je však značne svojvol'ný a umožňuje každý prameň interpretovat' viacerými protichodnými spôsobmi, čo je však očividne nesprávna cesta.

Razim si vo svojej knihe kladie otázky o autentickom presvedčení konkrétneho autora. Objektom skúmania sa tak stáva predovšetkým autor prameňa a jeho vlastné ideové koncepty. „Ako to bolo naozaj“, je otázka, ktorú sa Razim a mnohí d'alší pokúšajú dat' do čoraz silnejších úvodzoviek.

Aj napriek tejto opatrnosti je však teoreticky možné vytvorit' syntetizujúci pohl'ad na problematiku vztahu ríše a Čiech vo včasnom a vrcholnom stredoveku. Patrili Čechy do ríše, alebo ležali mimo nej? Nejednoznačnost' odpovedí v skúmaných 
prameňoch na túto otázku je možné nahradit využitím porovnávacieho materiálu. Přemyslovci totiž neboli jediní východní vládcovia, „stýkajúci sa a potýkajúci“ s panovníkmi stredovekej rímskej ríše. V rôznej škále integrovanosti sa nachádzali Korutánci a ich kniežatá, Moravania a ich Mojmírovci, skúsenosti so záväzkami voči sálskym panovníkom mali tiež Piastovci a Arpádovci, a svoju vlastnú perspektívu razili polabskí Slovania. Z obmedzenej perspektívy 10. a 11. storočia sa nám Čechy a Morava môžu javit' ako zvláštne zoskupenie so zvláštnymi vztahmi k ríši, ale napokon aj sama ríša bola tažko uchopitel'ným celkom, ktorý asi najviac zosobňoval jej král' (cisár). Hoci môžu vel'ké komparácie krívat' na obe nohy, predsa by azda bolo chybou ju vynechat pri odpovedi na otázku, ako to bolo s pozíciou Čiech v rámci ríšskych mocenských a právnych štruktúr.

Monografia Jakuba Razima je detailnou reflexiou predovšetkým postojov autorov klúčových ríšskych naračných diel voči včasnostredovekým Čechám a Morave a ich přemyslovským vládcom. Veríme, že bude patrit' $\mathrm{k}$ dôležitým medzníkom v stredoeurópskej medievistike.

Doc. Mgr. Miroslav Lysý, PhD.

Katedra právnych dejín a právnej komparatistiky

Právnická fakulta

Univerzita Komenského

Šafárikovo nám. č. 6

81000 Bratislava

miroslav.lysy@flaw.uniba.sk 